34. Maurel, C. and Maurel, P., E'tude expe'rimental de la distribution de l'aluminium entre bain silicate basique et spinelle chromife're. Implications pe'trogenetiques: teneur en chrome des spinelles. Bull. Mineral., 1982, 105, 197-202.

35. Wilson, M., Igneous Petrogenesis: A Global Tectonic Approach, Unwin Hyman, London, UK, 1989, p. 446.

36. Rollinson, H., The geochemistry of mantle chromitites from the northern part of the Oman ophiolite: inferred parental melt compositions. Contrib. Mineral. Petrol., 2008, 156, 273-288.

37. Kamenetsky, V. S., Crawford, A. J. and Meffre, S., Factors controlling chemistry of magmatic spinel: an empirical study of associated olivine, $\mathrm{Cr}$-spinel and melt inclusions from primitive rocks. J. Petrol., 2001, 42, 655-671.

38. Ravikant, V., Pal, T. and Das, D., Chromites from the Nidar ophiolite and Karzok complex, Trans Himalaya, eastern Ladakh: their magmatic evolution. J. Asian Earth Sci., 2004, 24, 177-184.

39. Ghosh, B., Pal, T., Bhattacharya, A. and Das, D., Petrogenetic implications of ophiolitic chromite from Rutland Island, Andaman a boninitic parentage in supra-subduction setting. Mineral. Petrol., 2009, 96, 59-70.

40. Singh, A. K., Chung, S. L., Bikramaditya, R. K. and Lee, H. Y., New $\mathrm{U}-\mathrm{Pb}$ zircon ages of plagiogranites from the NagalandManipur Ophiolites, Indo-Myanmar Orogenic Belt, NE India. $J$. Geol. Soc., London, 2017, 174, 170-179.

41. Azimzadeh, A. M., Zaccarini, F., Moayyed, M., Garuti, G., Thalhammer, O. A. R., Uysal, I. and Mirmohammadi, M., Magmatic and post-magmatic significance of chromitite and associated platinum-group minerals (PGM) in the Eastern Khoy ophiolitic complex (NW Iran). Ofioliti, 2011, 36, 157-173.

42. González-Jiménez, J. M., Proenza, J. A., Gervilla, F., Melgarejo, J. C., Blanco-Moreno, J. A., Ruiz-Sánchez, R. and Griffin, W. L., High-Cr and high-Al chromitites from the Sagua de Tánamo district, Mayarí-Cristal Ophiolitic Massif (eastern Cuba): constraints on their origin from mineralogy and geochemistry of chromian spinel and platinum-group elements. Lithos, 2011, 125, 101-121.

43. Vidyadharan, K. T., Joshi, A., Ghose, S., Gaur, M. P. and Sukla, R., Manipur Ophiolites. Its geology, tectonic setting and metallogeny. In Phanerozoic Ophiolites of India (ed. Ghose, N. C.), Sumna Publication, Patna, 1989, pp. 197-212.

44. Pearce, J. A., Barker, P. F., Edwards, S. J., Parkinson, I. J. and Leat, P. T., Geochemistry and tectonic significance of peridotites from the South Sandwich arc-basin system, South Atlantic. Contrib. Mineral. Petrol., 2000, 139, 36-53.

ACKNOWLEDGEMENTS. We thank the Director, Wadia Institute of Himalayan Geology, Dehradun for encouragement and providing the necessary laboratory facilities. This study was supported by the Ministry of Earth Sciences (MoES), Government of India through a research grant (No. MoES/P.O.(Geo)/80/2015) to A.K.S. We thank the two anonymous reviewers for useful suggestions and Prof. N. V. Chalapathi Rao for his editorial handling of this manuscript.

Received 30 June 2020; revised accepted 31 December 2020

doi: $10.18520 / \mathrm{cs} / \mathrm{v} 120 / \mathrm{i} 8 / 1381-1388$

\section{Food plasticity for mating and reproductive success in Propylea dissecta (Mulsant) (Coleoptera: Coccinellidae)}

\author{
Priya Singh, Geetanjali Mishra and Omkar* \\ Ladybird Research Laboratory, Department of Zoology, \\ University of Lucknow, Lucknow 226 007, India
}

Food supply at each life stage is of prime importance that determines the organism's fitness and also influences individual's reproductive performance and development. In this contest, we assessed the interactive effect of both larval and adult food regimes in Propylea dissecta (Mulsant) individuals. For this, egg batches were randomly selected and hatched larvae (larval diet) were reared into two food regimes, abundant (A) and scarce (S) till pupation. Post-emergence (adult stage) the ladybird beetles of each food regime were divided into two groups, abundant and scarce and at the age of 10 days adults were paired in all possible combinations. The results showed that individuals that were reared on abundant food mated for longer and showed higher reproductive output than other individuals. The adults provided with scarce and abundant food regime both irrespective of life stages showed similar mating durations and reproductive output. Food supply at larval and adult stages in both sexes plays important role in determining the reproductive success.

Keywords: Fecundity, food supply, ladybird, reproduction, viability.

THE distribution and allocation of resources has critical consequences on individual's development and growth ${ }^{1-3}$. In particular, the accessibility of adequate food supply is one of the prime factors modifying growth of organism, development and reproduction in animals ${ }^{4-6}$.

Food quality and quantity can fluctuate extensively in different landscapes ${ }^{7}$ and food shortage during larval development increases the duration of development. Food scarcity also decreases organisms growth rate and body mass as well as modifies the individuals reproductive output in later lives ${ }^{5,8,9}$.

Earlier studies have reported that both larval and adult stages of ladybird beetles have potential to survive in prolonged food stress conditions ${ }^{10,11}$, but their reproductive performance might be a constraint in comparison to adults given opportunity to feed on ad libitum aphid supply $^{12-14}$. Few more studies have found that the food available to coccinellid larvae has a direct influence on the reproductive fitness of the resulting adults ${ }^{14-16}$. Dixon and Guo ${ }^{17}$ suggested that this may be the result of food

*For correspondence. (e-mail: omkar.lkouniv@gmail.com) 


\section{RESEARCH COMMUNICATIONS}

consumption at larval stages that shows on adult size and variation in ovariole number. Although food in terms of quantity for larval development and adult reproduction have been well studied ${ }^{15,18,19}$, there are no attempts made so far to differentiate between the consequences of food availability through larval and adult diet altogether in adults.

Ladybird beetles are efficient bio-control agents because they predate on aphids, eggs of mites, cochineals and aleyrodids ${ }^{19,20}$. Larval growth and adult fecundity are directly affected by the ephemeral nature of these pest populations. Larvae developing in food-stressed conditions turn out into smaller adults ${ }^{21,22}$. Studies in ladybirds have shown that female oviposition decreases with maternal size and males also decrease their ejaculate size and accessory gland proteins which is directly dependent on the food accessibility at the time of growth and development ${ }^{23-25}$. If the energy for maintenance is reduced, the life span becomes shorter and energy can be curtailed for survival rather than reproduction ${ }^{26}$ as reproduction is a costly event for both the sexes. A recent study in $P$. dissecta revealed that food supply at both larval and adult stage is essential in achieving higher mating success ${ }^{14}$. It has also been documented that food available at the time of egg laying plays a crucial role in optimizing their reproductive capacity ${ }^{14}$. However, less information is available on the interaction connecting larval and adult life stages in male and female ladybird beetles. Thus, it is important to understand how plasticity in food availability during larval and adults stages affect the mating individuals and their reproductive performance. In this paper, we examine the plasticity (i.e. condition dependent) of mating parameters and on reproduction in both the sexes of $P$. dissecta by manipulating food supply at their larval and adult life stages. Subsequently, based on these results, we examine the mating and reproductive strategies associated with condition-dependent in P. dissecta.

Propylea dissecta (Mulsant), an aphidophagous ladybird beetle is quite common in agricultural and horticultural landscapes of North India ${ }^{27}$. It is polymorphic with three morphspale, intermediate and typical ${ }^{28}$. The sex differentiation is quite prominent in $P$. dissecta. The sexspecific characteristic for females are black markings on their head and pronotum whereas a white band marking on pronotum and head clearly demarcated males ${ }^{29}$.

Adults of $P$. dissecta of mixed body sizes of typical morph were collected from the agricultural fields in Lucknow, India $\left(26^{\circ} 50^{\prime} \mathrm{N}, 80^{\circ} 54^{\prime} \mathrm{E}\right)$. Field collected adults were paired in transparent plastic petri dishes $\left(14.5 \times 1.5 \mathrm{~cm}^{2}\right.$, one pair per dish) and placed in Biochemical Oxygen Demand (BOD) incubators (Yorco Super Deluxe, YSI-440 New Delhi, India) at $27 \pm 2{ }^{\circ} \mathrm{C}$, $65 \pm 5 \% \mathrm{RH}$ and $14 \mathrm{~L}: 10 \mathrm{D}$ photoperiod. They were given ad libitum daily replenished supply of bean aphid, $A$. craccivora (reared on host plant Vigna unguiculata L. in a greenhouse at $25 \pm 2{ }^{\circ} \mathrm{C}, 65 \pm 5 \%$ R.H. and $14 \mathrm{~L}: 10 \mathrm{D}$ photoperiod). The eggs laid were collected and larvae were reared till adult emergence and fed with ad libitum aphids till 10 days.

The 10-day-old adults were taken from the prepared stock and allowed to mate. Postmating females were separated for oviposition. Egg batches were randomly selected from the stock from their first day to fifth day. The hatched larvae (less than 2 hours old) were allowed in one of the two food regimes, i.e. abundant (A) and scarce (S) food (quantity followed as given in ref. 14), till pupation (larval food/pre-emergence regime). Postemergence, the individuals from each larval regime were again split into postemergence dietary regimes, viz. abundant and scarce (adult food regime; quantity of prey food followed as given in ref. 14). On day 10 postemergence, adults were paired and observed for mating in the following combinations: (1) $\mathrm{A}_{\mathrm{AA}} \hat{\jmath} \times \mathrm{A}_{\mathrm{AA}}$; ; (2) $\mathrm{A}_{\mathrm{AA}} \hat{\jmath} \times \mathrm{A}_{\mathrm{AS}}+$; (3) $\mathrm{A}_{\mathrm{AA}} \hat{\bigcirc} \times \mathrm{A}_{\mathrm{SA}}$; ; (4) $\mathrm{A}_{\mathrm{AA}} \hat{\bigcirc} \times \mathrm{A}_{\mathrm{SS}+}$; (5) $\mathrm{A}_{\mathrm{AS}+}+\mathrm{A}_{\mathrm{AA}+}$; (6) $\mathrm{A}_{\mathrm{AS}} \hat{\bigcirc} \times \mathrm{A}_{\mathrm{AS}+}$; (7) $\mathrm{A}_{\mathrm{AS}} \hat{\bigcirc} \times \mathrm{A}_{\mathrm{SA}}$; ; (8) $\mathrm{A}_{\mathrm{AS}} \hat{\jmath} \times \mathrm{A}_{\mathrm{SS}+}$;

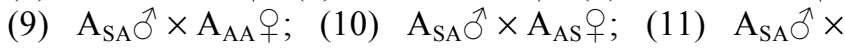
$\mathrm{A}_{\mathrm{SA}}$; ; (12) $\mathrm{A}_{\mathrm{SA}} \hat{\jmath} \times \mathrm{A}_{\mathrm{SS}}+$; (13) $\mathrm{A}_{\mathrm{SS}} \hat{\jmath} \times \mathrm{A}_{\mathrm{AA}}$; ;

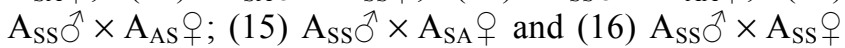
(subscripts denote the food regime abundant (A) and scarce (S) larval and adult life stages respectively). The mating parameters, viz. time to commence to mating (TCM: time from the instant of cohabitation to mounting of male over female) and mating duration (MD: time taken from intromission till the male dismounting) were recorded. Postmating females were provided with optimal food regime $(20 \mathrm{mg}$ ) and fecundity (number of eggs laid), and per cent egg viability (number of eggs hatched $x$ $100 /$ total number of eggs) was recorded for five consecutive days. Data for $\mathrm{A}_{\mathrm{AA}} \hat{\bigcirc} \times \mathrm{A}_{\mathrm{AA}} \mathrm{O} ; \mathrm{A}_{\mathrm{AS}} \hat{\bigcirc} \times \mathrm{A}_{\mathrm{AS}} \mathrm{O}$; $\mathrm{A}_{\mathrm{SA}} \hat{\circlearrowright} \times \mathrm{A}_{\mathrm{SA}} \oslash ; \mathrm{A}_{\mathrm{SS}} \hat{\jmath} \times \mathrm{A}_{\mathrm{SS}} \odot$ treatments were taken from ref. 13 as offspring of these pairs was used in a transgenerational study. Each treatment was replicated 12 times.

Data of dependent variables which includes time to commence mating, mating duration, fecundity and per cent egg viability were tested for their normal (Kolmogorov-Smirnov's test) and homogenous (Bartlett's test) distribution. Data collected were analysed by generalized linear model with adults food regime (male and female) treated as independent factors while time to commence mating, mating duration, fecundity and per cent egg viability were considered as dependent factors. All statistical analyses were conducted using SPSS (version 20.0, SPSS Company, Chicago, USA) statistical software.

Generalized linear model revealed that both male $(W=54.683, \quad P<0.0001, \quad \mathrm{~d} f=3,189)$ and female ( $W=56.08, P=P<0.0001, \mathrm{~d} f=3,189$ ) feeding regimes significantly influenced the time to commence mating. The interaction between these two factors was significant $(W=18.973, P=0.025, \mathrm{~d} f=9,183)$. The less time to commence mating was in those pairs which were fed on abundant feeding regime. The larval and adult food regime of both sexes played a decisive role in determining 
time to commence mating however food regime at adult stage had more impact (Figure $1 a$ ).

Mating duration was significantly modified by both male $(W=118.661, P<0.0001, \mathrm{~d} f=3,189)$ and female food regimes $(W=129.823, P<0.0001, \mathrm{~d} f=3,189)$. The interaction between the two given food regimes $(W=$ 46.981, $P<0.0001, \mathrm{~d} f=9,183$ ) significantly influenced mating duration. The adults with scarce and abundant food regime irrespective of the sequence of diet regimes showed similar mating durations (Figure $1 b$ ).

Fecundity was affected significantly by male $(W=$ 366.491, $P<0.0001, \mathrm{~d} f=3,189)$ and female $(W=$ 286.754, $P<0.0001, \mathrm{~d} f=3,189)$ feeding regimes. Interactions between male and female feeding regimes ( $W=38.809, P<0.0001, \mathrm{~d} f=9,183)$ also had significant effect. The fecundity of $\mathrm{A}_{\mathrm{AA}} \rightarrow$ differed with male regime. $\mathrm{A}_{\mathrm{AA}}$ 早 laid the maximum number of eggs when mated with $\mathrm{A}_{\mathrm{AA}} \hat{\jmath}$, followed by mating with $\mathrm{A}_{\mathrm{AS}} \hat{\jmath}, \mathrm{A}_{\mathrm{SA}} \hat{\sigma}$ and $\mathrm{A}_{\mathrm{SS}} \mathrm{O}^{\mathrm{A}}$. Minimum fecundity was observed in pairs with

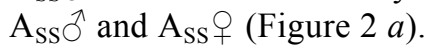

Per cent egg viability was significantly influenced by male $(W=67.613, P<0.0001, \mathrm{~d} f=3,189)$ and female $(W=35.967, P<0.0001, \mathrm{~d} f=3,189)$ feeding regimes, however the interaction between male and female feeding regime was insignificant $(W=3.017, P=0.964, \mathrm{~d} f=9$, 183). Ladybirds reared on abundant food regime had

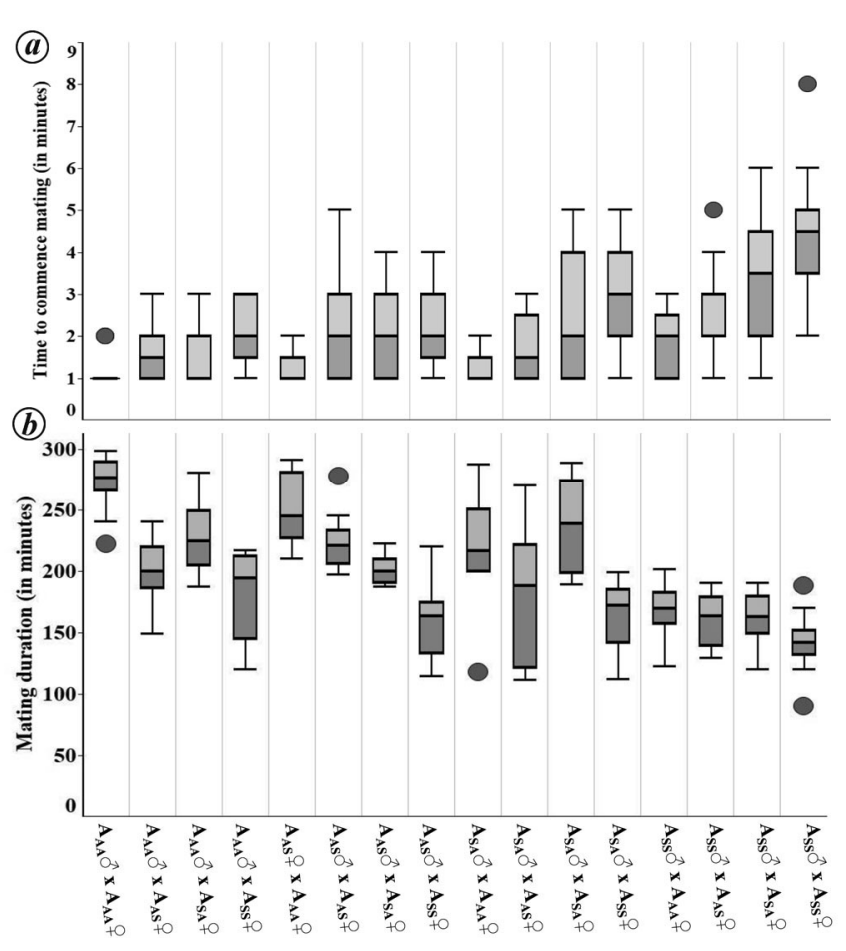

Figure 1. Box and whisker plot showing effect of food quantity on (a) time to commence mating and (b) mating duration in Propylea dissecta. The horizontal line within the box marks the median. The vertical lines extending from the box are 1.5 times the length of the box. Circles represent outliers. Subscripts on $X$-axis denote the food regime abundant (A) and scarce (S) at larval and adult stage respectively. highest egg viability. Egg viability differed for $\mathrm{A}_{\mathrm{AA}} \widehat{O}^{\lambda}$ with the variation in female nutritional status. Similarly it also varies with difference in male nutritional status with $\mathrm{A}_{\mathrm{AA}}$ ㅇ (Figure $2 b$ ).

Adults reared on abundant food regime post eclosion were found to be more successful in maximizing their reproductive success than their counterparts. Our results show that if there was food stress at the time of early growth and development, it can reduce the lifetime fitness of individuals via modifying the body mass and energy reserves, generally considered being free from adult environment ${ }^{22}$. The successful growth and development of adults under food limited conditions is suggestive towards the competency of ladybird beetles to cope even in detrimental conditions.

When limited food was provided at both life stages, males took longer to establish mating. However, male and female food regime of both the sexes affected time to commence mating. The enhanced mating performance achieved by adults fed on abundant food regime may reflect conditional response. Previous studies have documented that individuals fed on ad libitum food supply get benefitted in various ways than individuals from poor food environment. These individuals also have longer copulations and greater oviposition ${ }^{7,30-32}$. Few earlier studies have mentioned that males subjected to good food

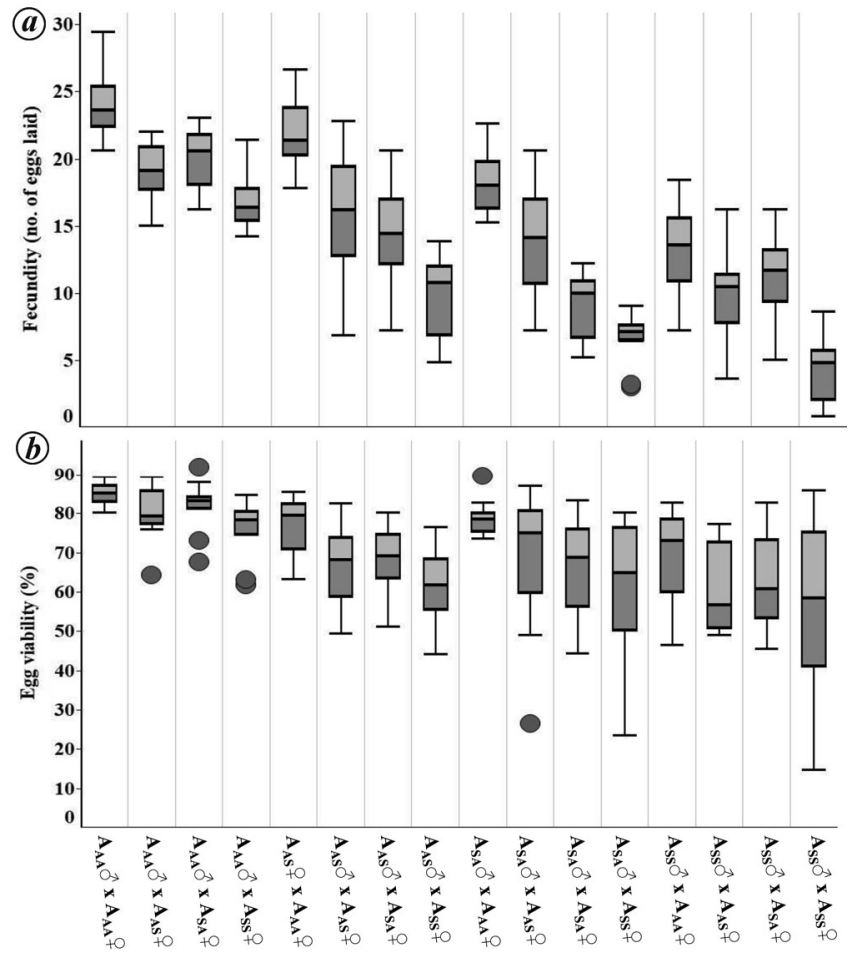

Figure 2. Box and whisker plot showing effect of food quantity on (a) fecundity and (b) per cent egg viability in Propylea dissecta. The horizontal line within the box marks the median. The vertical lines extending from the box are 1.5 times the length of the box. Circles represent outliers. Subscripts on $X$-axis denote the food regime abundant (A) and scarce (S) at larval and adult stage respectively. 


\section{RESEARCH COMMUNICATIONS}

supply deliver large quantities of ejaculates having more ACP's and thus possibly may be chosen as mates above males reared in poor conditions ${ }^{33,34}$.

In the present study, fecundity found to be a much better speculator of reproductive fitness following various food regimes than viability of eggs in $P$. dissecta. Maximum oviposition was observed by females fed on abundant food regime during larval and adult life stages. This is in accordance with previous studies elaborating that egg-clutch size and ovipositional rate is regulated by the quantity of food available at the time of female oviposition $^{17,18}$. Reduction in female fecundity under poor food supply has been attributed to: (i) deficiency of dietary proteins which facilitates the female oogenesis ${ }^{35,36}$, (ii) decrease in sperm production including ancillary fluids, which in turn can reduce or limit female oviposition ${ }^{16,37}$ and (iii) reabsorption of eggs in female genitalia or holding back of oviposition under scarce or poor food conditions $^{38,39}$. These reasons collectively or individually can modify the female fecundity.

The pairs with ad libitum food supply at both life stages laid most viable eggs. For males and females, food supply at both the stages plays crucial role in achieving higher egg viability. The reduced viability was recorded in the pairs having scarce diet. The reduction in egg viability may be due to: (i) decrease yolk quality and quantity owing to deficient nutrients, which might not be enough to trigger or strengthen development ${ }^{2,3,40}$ and (ii) reduction in sperm production because of low rate of spermatogenesis in male genitalia and sperm survival in the females genitalia ${ }^{41}$. However, the pairs with abundant and scarce diet at larval and adult stages or vice versa with moderate viability show that they are capable of allocating resources and maximizing their fitness in the fluctuating environmental conditions.

This study highlights the effect of prey food supply to larval and adult life stages of $P$. dissecta on mating and oviposition success. Food supply in both the life stages play a conspicuous role for sexes in their development and establishment of mating. Individuals reared on scarce food post-eclosion but with their larvae fed ad libitum food had reduced mating and reproductive output. The pairs reared on both scarce and abundant food regime through their larval and adult food regime or vice versa are able to survive prolonged food stress but the reduction in their reproductive performance was recorded relative to the adults fed on abundant food. The high estimating and reproductive success was accomplished by adults reared on abundant food regime, indicating that food supply contributes a crucial role in growth, development and reproductive success which latently drives their ecological and population dynamics.

1. Jervis, M. A. and Ferns, P. N., The timing of egg maturation in insects: ovigeny index and initial egg load as measures of fitness and of resource allocation. Oikos, 2004, 107(3), 449-461.
2. Boggs, C. L. and Freeman, K. D., Larval food limitation in butterflies: effects on adult resource allocation and fitness. Oecologia, 2005, 144, 353-361.

3. Geister, T. L., Lorenz, M. W., Hoffmann, K. H. and Fischer, K., Adult nutrition and butterfly fitness: effects of diet quality on reproductive output, egg composition, and egg hatching success. Front. Zool., 2008, 5, 10.

4. Auer, S. K., Arendt, J. D., Chandramouli, R. and Reznick, D. N., Juvenile compensatory growth has negative consequences for reproduction in Trinidadian guppies (Poecilia reticulata). Ecol. Lett., 2010, 13, 998-1007.

5. Dmitriew, C. M., The evolution of growth trajectories: what limits growth rate?. Biol. Rev., 2011, 86, 97-116.

6. Zeller, M. and Koella, J. C., Effects of food variability on growth and reproduction of Aedes aegypti. Ecol. Evol., 2016, 6(2), 552-559.

7. Hebets, E. A., Wesson, J. and Shamble, P. S., Diet influences mate choice selectivity in adult female wolf spiders. Anim. Behav., 2008, 76, 355-363.

8. Blanckenhorn, W. U., Adaptive phenotypic plasticity in growth, development and body size in the yellow dung fly. Evolution, 1998, 52, 1394-1407.

9. Fischer, K. and Fiedler, K., Effects of larval starvation on adult life-history traits in the butterfly species Lycaena tityrus (Lepidoptera: Lycaenidae). Entomol. Gen., 2001, 25, 249-254.

10. Pervez, A. and Omkar, Influence of prey deprivation on biological attributes of pale morphs of the ladybeetle, Propylea dissecta (Mulsant). Int. J. Tropic. Insect Sci., 2003, 23, 143-148.

11. Pervez, A. and Omkar, Predation potential and handling time estimates of a generalist aphidophagous ladybird, Propylea dissecta. Biologic. Memo. Lucknow, 2003, 29, 91-97.

12. Koch, R. L., The multicolored Asian lady beetle, Harmonia axyridis: a review of its biology, uses in biological control, and nontarget impacts. J. Insect Sci., 2003, 3, 1-16.

13. Dmitriew, C. and Rowe, L., Effects of early resource limitation and compensatory growth on lifetime fitness in the ladybird beetle (Harmonia axyridis). J. Evol. Biol., 2007, 20, 1298-1310.

14. Singh, P., Mishra, G. and Omkar, Are the effects of hunger stagespecific? A case study in an aphidophagous ladybird beetle. Bull. Entomol. Res., 2021, 111, 66-72.

15. Ware, R. L., Yguel, B. and Majerus, M. E., Effects of larval diet on female reproductive output of the European coccinellid Adalia bipunctata and the invasive species Harmonia axyridis (Coleoptera: Coccinellidae). Euro. J. Entomol., 2008, 105, 437.

16. Omkar, Sahu, J. and Kumar, G., Effect of prey quantity in a ladybird beetle, Anegleis cardoni (Weise) (Coleoptera: Coccinellidae). Int. J. Tropic. Insect Sci., 2010, 30, 48-56.

17. Dixon, A. F. G. and Guo, Y. Q., Egg and cluster size in ladybird beetles (Coleoptera, Coccinellidae) the direct and indirect effects of aphid abundance. Euro. J. Entomol., 1993, 90, 457-463.

18. Michaud, J. P., On the assessment of prey suitability in aphidophagous Coccinellidae. Euro. J. Entomol., 2005, 102, 385.

19. Omkar and Pervez, A., Prey preference of a ladybeetle, Micraspis discolor (Fabricius). Entomon, 2001, 26, 195-197.

20. Ragkou, V. S., Athanassiou, C. G., Kavallieratos, N. G. and Tomanović, Ž., Daily consumption and predation rate of different Stethorus punctillum instars feeding on Tetranychus urticae. Phytoparasitica, 2004, 32, 154-159.

21. Agarwala, B. K., Bardhanroy P., Yasuda, H. and Takizawa, T., Prey consumption and oviposition of the aphidophagous predator Menochilus sexmaculatus (Coleoptera: Coccinellidae) in relation to prey density and adult size. Environ. Entomol., 2001, 30,11821187.

22. Dmitriew, C. and Rowe, L., The effects of larval nutrition on reproductive performance in a food-limited adult environment. PLOS ONE, 2011, 6, e17399.

23. Hodek, I. and Honek, A., Ecology of Coccinellidae, Kluwer, Dordrecht, 1996, p. 464. 
24. Hodek, I. and Evans, E. W., Food relationships. In Ecology and Behaviour of the Ladybird Beetles (Coccinellidae) (eds Hodek, I., van Emden, H. F. and Honek, A.), Wiley-Blackwell, Oxford, 2012, pp. 141-274.

25. Perry, J. C. and Rowe, L., Condition-dependent ejaculate size and composition in a ladybird beetle. Proc. R. Soc. B: Biol. Sci., 2010, 277(1700), 3639-3647.

26. Skorupa, D. A., Dervisefendic, A., Zwiener, J. and Pletcher, S. D., Dietary composition specifies consumption, obesity, and lifespan in Drosophila melanogaster. Aging Cell, 2008, 7, 478-490.

27. Omkar and Pervez, A., Biodiversity of predaceous coccinellids (Coleoptera: Coccinellidae) in India: a review. J. Aphidol., 2000, 14, 41-66.

28. Pervez, A., Contribution on prey-predator relationship and reproductive biology of a colour morph of Propylea dissecta (Mulsant) (Coccinellidae: Coleoptera). Ph.D. thesis, University of Lucknow, India, 2002.

29. Omkar and Pervez, A., Sexual dimorphism in Propylea dissecta (Mulsant), (Coccinellidae: Coleoptera). J. Aphidol., 2000, 14, 139-140.

30. Engqvist, L. and Sauer, K. P., Influence of nutrition on courtship and mating in the scorpionfly Panorpa cognata (Mecoptera, Insecta). Ethology, 2003, 109, 911-928.

31. Eraly, D., Hendrickx, F. and Lens, L., Condition-dependent mate choice and its implications for population differentiation in the wolf spider Pirata piraticus. Behav. Ecol., 2009, 20, 856-863

32. Albo, M. J., Toft, S. and Bilde, T., Female spiders ignore condition-dependent information from nuptial gift wrapping when choosing mates. Anim. Behav., 2012, 84, 907-912.

33. Gwynne, D. T., Testing parental investment and the control of sexual selection in katydids: the operational sex ratio. Am. Nat., 1990, 136, 474-484.

34. Perry, J. C., Sharpe, D. M. and Rowe, L., Condition-dependent female remating resistance generates sexual selection on male size in a ladybird beetle. Anim. Behav., 2009, 77, 743-748.

35. Cope, J. M. and Fox, C. W., Oviposition decisions in the seed beetle, Callosobruchus maculatus (Coleoptera: Bruchidae): effects of seed size on superparasitism. J. Stored Prod. Res., 2000, 39, $355-365$.

36. Terashima, J. and Bownes, M., Translating available food into the number of eggs laid by Drosophila melanogaster. Genetics, 2004, 167, 1711-1719.

37. Droney, D. C., Environmental influences on male courtship and implications for female choice in a lekking Hawaiian Drosophila. Anim. Behav., 1996, 51, 821-830.

38. Boggs, C. L. and Ross, C. L., The effect of adult food limitation on life history traits in Speyeria mormonia (Lepidoptera: Nymphalidae). Ecology, 1993, 74, 433-441.

39. Rosenheim, J. A., Heimpel, G. E. and Mangel, M., Egg maturation, egg resorption and the costliness of transient egg limitation in insects. Proc. R. Soc. London, Ser. B: Biol. Sci., 2000, 267(1452), 1565-1573.

40. Omkar and Barish, E. J., Influence of prey species on immature survival, development, predation and reproduction of Coccinella transversalis Fabricius (Col., Coccinellidae). J. Appl. Entomol., 2004, 128, 150-157.

41. Ponsonby, D. J. and Copland, M. J. W., Environmental influences on fecundity, egg viability and egg cannibalism in the scale insect predator, Chilocorus nigritus. BioControl, 1998, 43, 39-52.

42. Dixon, A. F. G., Insect Predator-Prey Dynamics: Ladybird Beetles and Biological Control, Cambridge University Press, 2000, p. 257.

ACKNOWLEDGEMENTS. We acknowledge Department of Zoology, University of Lucknow, Lucknow, Uttar Pradesh, India for providing the facilities for this research.

Received 8 December 2020; revised accepted 10 February 2021

doi: $10.18520 / \mathrm{cs} / \mathrm{v} 120 / \mathrm{i} 8 / 1388-1392$ 